\title{
Skutki prawne zaciągania przez samorządy terytorialne kredytów konsolidacyjnych w świetle obowiązujących regulacji ustawy o finansach publicznych wraz z oceną możliwości dokonania zmian w tym zakresie ${ }^{1}$
}

Legal effects of contracting consolidation credits by local self-governments in the light of current provisions of the Act on Public Finances, along with an assessment of the possibility of future changes in this respect (WASiE 268/18): Within the current state of law, all activities related to contracting a consolidation credit must be included as a revenue and expenditure in the budgetary resolution of a local self-government unit, at the same time affecting the amount of an individual debt ratio. There is no legal basis for directing instructions to the Regional Audit Chambers to change an interpretation of the currently binding legal norms. An amendment to the Act on Public Finances is in the process of drafting, aiming at making possible for local self-government entities to restructure debt through, inter alia, repayment of the existing debt with a new, more favorable consolidation debt.

Keywords: public finance, credit, local self-government, debt

Słowa kluczowe: finanse publiczne, kredyt, samorząd terytorialny, zadłużenie

Doktor hab. nauk prawnych, profesor Uniwersytetu Łódzkiego, ekspert ds. legislacji BAS; hdzwonkowski@poltax.pl.

\section{Przedmiot opinii}

Celem niniejszej opinii jest dokonanie analizy problemów prawno-finansowych, o których mowa w piśmie Prezydenta Miasta Przemyśla z 17 stycznia 2018 r.

Opinia prawna w przedmiocie stanowiska zawartego w piśmie Prezydenta Miasta Przemyśla $z$ dnia 17 stycznia 2018 r. dotycząca skutków prawnych związanych $z$ zaciaganiem przez poszczególne samorządy terytorialne kredytów konsolidacyjnych $w$ świetle obowiązujących regulacji ustawy o finansach publicznych wraz z ocena możliwości dokonania zmian w tym zakresie sporządzona 6 marca 2018 r. na zlecenie p.o. dyrektora generalnego kierującego Gabinetem Marszałka Sejmu; BAS-WASiE 268/18. 
(znak: KPM.033.13.2018), skierowanym m.in. do Marszałka Sejmu RP oraz Ministra Finansów. W piśmie stwierdzono, że miasto Przemyśl, podobnie jak wiele innych ośrodków o porównywalnej wielkości i potencjale gospodarczym, jest żywotnie zainteresowane czynnym udziałem w projektach opracowywanych w ramach „Strategii odpowiedzialnego rozwoju”, w tym przede wszystkim w ogłoszonym w Przemyślu „Pakiecie dla średnich miast”, którego celem jest wyrównanie szans rozwojowych wszystkich obszarów miejskich, w szczególności tych z największymi problemami społeczno-gospodarczymi. Warunkiem uczestnictwa $\mathrm{w}$ tego typu inicjatywach jest jednak konieczność zagwarantowania odpowiedniej kondycji finansowej beneficjenta programu (m.in. zobowiązań i środków własnych). Istotną barierą w tym względzie staje się fakt, że istniejące zobowiązania jednostki samorządu terytorialnego ograniczają szanse na skorzystanie z dostępnych środków zewnętrznych, czyniąc ewentualny udział w programie „Pakietu dla średnich miast” praktycznie niemożliwym. Władze miasta Przemyśla dokonały zatem analizy możliwości zaciągnięcia kredytu konsolidacyjnego, który zmieniłby harmonogram spłaty istniejących zobowiązań. Okazało się jednak, że zgodnie ze stanowiskiem Regionalnej Izby Obrachunkowej w Rzeszowie oraz z orzecznictwem sądów administracyjnych, opartych na postanowieniach ustawy o finansach publicznych ${ }^{2}$, zaciągając tego typu kredyt, należy go uwzględniać (jako przychód i rozchód) w uchwale budżetowej. Prowadzi to do sytuacji, w której wyliczając indywidualny wskaźnik zadłużenia jednostki samorządu, po stronie rozchodów wymagane jest umieszczenie kwoty spłacanej kredytem konsolidacyjnym, co oznacza przekroczenie dopuszczalnego wskaźnika zadłużenia (w przypadku Przemyśla wskaźnik ten wzrasta z poziomu 4,68\% do 30,66\%), a tym samym konieczność stwierdzenia nieważności ewentualnej uchwały o zmianie uchwały budżetowej oraz uchwały o zaciągnięciu kredytu konsolidacyjnego.

W związku z powyższymi ustaleniami Prezydent Miasta Przemyśla zwraca się $\mathrm{z}$ wnioskiem o rozważenie:

- wydania wytycznych dla regionalnych izb rozrachunkowych w zakresie możliwości spłaty kredytów konsolidacyjnych, tak aby rozchód z tym związany nie wpływał negatywnie na ocenę przedsięwzięcia, a gdy nie będzie to możliwe w obecnym stanie prawnym,

- przeprowadzenie pilnej zmiany przepisów ustawy o finansach publicznych, aby uzyskanie kredytu konsolidacyjnego było w praktyce możliwe.

2 Ustawa z 27 sierpnia 2009 r. o finansach publicznych, t.j. Dz.U. 2017, poz. 2077, ze zm.; dalej: ustawa lub u.f.p. 


\section{Analiza zagadnienia}

Przystępując do oceny stanowiska wyrażonego w piśmie Prezydenta Miasta Przemyśla, w pierwszej kolejności należy zwrócić uwagę na uwarunkowania prawne związane z podnoszoną kwestią dotyczącą wpływu faktu zaciągnięcia kredytu konsolidacyjnego na sytuację dotyczącą stanu zadłużenia jednostki samorządu terytorialnego (w tym poziomu indywidualnego wskaźnika zadłużenia). Ustalenia w tym względzie determinują bowiem możliwość rozważenia na dalszym etapie opracowania propozycji wynikających z petycji Prezydenta Miasta Przemyśla.

Przede wszystkim należy sięgnąć do treści obowiązujących przepisów ustawy z 27 sierpnia 2009 r. o finansach publicznych. Ustawa ta w art. 5, dotyczącym środków publicznych, dokonuje wyliczenia poszczególnych rodzajów przychodów i rozchodów gromadzonych w budżecie państwa i budżetach jednostek samorządu terytorialnego oraz ujmowanych w planach finansowych jednostek sektora finansów publicznych. Klasyfikacja przyjęta w tym przepisie dzieli środki publiczne na podstawowe kategorie. Są nimi: dochody publiczne, przychody publiczne oraz środki pochodzące $\mathrm{z}$ budżetu UE i inne bezzwrotne środki ze źródeł zagranicznych, a także środki, o których mowa w ustawie o zasadach prowadzenia polityki rozwoju. Każda z tych kategorii środków publicznych została uszczegółowiona w kolejnych ustępach art. 5 u.f.p. I tak według ust. 1 pkt 4 lit. d środkami publicznymi są przychody budżetu państwa i budżetów jednostek samorządu terytorialnego oraz innych jednostek sektora finansów publicznych pochodzące z otrzymanych pożyczek i kredytów. W art. 5 ustawy posłużono się pojęciami „dochody” i „przychody”, podobnie jak w art. 6 użyto terminów „wydatki” i „rozchody”. Należy przy tym zaznaczyć, że przychody i rozchody są odrębnymi elementami funkcjonowania budżetu w stosunku do dochodów i wydatków. Dochody i wydatki mają charakter podstawowy, a przychody i rozchody uzupełniający, o cechach bankowo-kredytowych. W systemie przychodów budżetowych dominujące znaczenie mają przychody o charakterze zwrotnym³ ${ }^{3}$.

Warto również podkreślić, że w ust. 1 art. 6 określono przeznaczenie środków publicznych, wymienionych w art. 5, dzieląc je na wydatki publiczne i rozchody publiczne, w tym na rozchody budżetu państwa i budżetów jednostek samorządu terytorialnego, natomiast w ust. 2 wskazano rodzaje rozchodów publicznych, wymieniając, że rozchodami publicznymi są m.in.: spłaty otrzymanych pożyczek i kredytów (pkt 1), a także udzielone pożyczki i kredyty (pkt 3).

Mając na uwadze powyższe, należy również stwierdzić, że rozróżnienie wydatków od rozchodów opiera się na kryterium ekonomicznym. Wydatki wiązać należy z redystrybucją definitywną (np. zapłata za towary lub usługi, wypłata wynagrodzeń). Rozchody są związane z czasowym transferem środków. Rozchody

3 Zob. L. Lipiec-Warzecha, Komentarz do art. 5 ustawy o finansach publicznych, LEX. 
publiczne wynikają z konieczności realizacji zobowiązań zaciągniętych uprzednio przez jednostkę sektora finansów publicznych (np. spłata pożyczki lub kredytu) albo wykonania obowiązków umownych polegających na udostępnieniu publicznych zasobów finansowych innym podmiotom (np. udzielenie pożyczki). Wydatki publiczne mają zatem charakter ostateczny, czyli bezzwrotny, a rozchody publiczne cechuje zwrotny charakter płatności. Wyodrębnienie rozchodów umożliwia zachowanie przejrzystości budżetu. Spłata zobowiązań nie stanowi wydatku publicznego. Wydatkiem jest natomiast spłata odsetek i obsługa długu. Ujęte w budżecie państwa, budżetach samorządu terytorialnego oraz w planach finansowych jednostek sektora finansów publicznych wydatki oraz rozchody stanowią nieprzekraczalny limit zwrotny ${ }^{4}$.

Rozwinięcie przedstawionych reguł związanych z przychodami i rozchodami następuje $\mathrm{w}$ art. 89 u.f.p. określającym cele, które mogą być sfinansowane środkami pochodzącymi z kredytu lub pożyczki albo ze sprzedaży papierów wartościowych wyemitowanych przez jednostkę samorządu terytorialnego (ust. 1), m.in. na spłatę wcześniej zaciągniętych zobowiązań z tytułu emisji papierów wartościowych oraz zaciągniętych pożyczek i kredytów (pkt 3). W dalszej kolejności należy wymienić kluczowy dla analizowanej sprawy przepis art. 91 u.f.p. Zgodnie z nim suma zaciągniętych kredytów i pożyczek oraz zobowiązań z wyemitowanych papierów wartościowych, o których mowa w art. 89 ust. 1 ustawy (w tym na spłatę wcześniej zaciągniętych zobowiązań z tytułu zaciągniętych pożyczek i kredytów), nie może przekroczyć kwoty określonej w uchwale budżetowej jednostki samorządu terytorialnego (ust. 1). W przypadku ubiegania się przez jednostkę samorządu terytorialnego o kredyt lub pożyczkę na cel, o którym mowa w art. 89 ust. 1 pkt $2-4$, a także w przypadku zamiaru emisji przez jednostkę samorządu terytorialnego papierów wartościowych na cel, o którym mowa w tym samym przepisie, zarząd tej jednostki jest obowiązany uzyskać opinię regionalnej izby obrachunkowej o możliwości spłaty kredytu lub pożyczki albo wykupu papierów wartościowych (ust. 2).

Jak wynika $\mathrm{z}$ dotychczasowych ustaleń, wymieniony przepis art. 91 u.f.p. w ust. 1 dopuszcza zaciąganie zobowiązań z tytułu kredytów, pożyczek lub wyemitowanych papierów wartościowych do wysokości limitu określonego w uchwale budżetowej. Ograniczenie w korzystaniu ze środków zwrotnych, polegające na obligatoryjnym ustaleniu ich limitu kwotowego w uchwale budżetowej, obejmuje m.in. spłatę wcześniej zaciągniętych zobowiązań z tytułu pożyczek i kredytów. Limit zobowiązań jest obligatoryjnym elementem uchwały budżetowej jednostki samorządu. Oznacza to, że jeśli uchwała budżetowa danej jednostki na dany rok budżetowy nie zawiera - mimo ustawowego wymogu - tego limitu, to gmina nie może zaciągać kredytów lub pożyczek ${ }^{5}$. Zatem ujęcie w uchwale budżetowej

4 Zob. L. Lipiec-Warzecha. Komentarz do art. 6 ustawy o finansach publicznych, LEX.

5 Zob. L. Lipiec-Warzecha. Komentarz do art. 91 ustawy o finansach publicznych, LEX. 
stosownych przychodów determinuje możliwość zaciągania kredytu długoterminowego na spłatę wcześniej zaciągniętych zobowiązań.

Legalną definicję budżetu jednostki samorządu terytorialnego zawiera z kolei norma $\mathrm{z}$ art. 211 u.f.p. Zgodnie $\mathrm{z}$ nią: Budżet jednostki samorządu terytorialnego jest rocznym planem dochodów $i$ wydatków oraz przychodów i rozchodów tej jednostki (ust. 1). Budżet jednostki samorzadu terytorialnego jest uchwalany na rok budżetowy (ust. 2). Rokiem budżetowym jest rok kalendarzowy (ust. 3). Podstawa gospodarki finansowej jednostki samorzadu terytorialnego w danym roku budżetowym jest uchwała budżetowa (ust. 4). Z tak sformułowanej definicji wynikają następujące cechy budżetu jednostki samorządu terytorialnego:

- jest on planem dochodów i wydatków,

- ma charakter roczny,

- jest uchwalany w formie uchwały budżetowej na okres roku budżetowego,

- uchwała budżetowa (której najistotniejszym elementem jest budżet) stanowi podstawę gospodarki finansowej jednostki samorządu terytorialnego w roku budżetowym.

Jednocześnie warto wskazać, że z kolei przepis art. 212 ust. 1 pkt 6 u.f.p. stanowi, że uchwała budżetowa określa: limit zobowiązań z tytułu zaciaganych kredytów i pożyczek oraz emitowanych papierów wartościowych, o których mowa $w$ art. 89 ust. 1 i art. 90 ustawy (w tym również kredytów zaciągniętych na spłatę wcześniej zaciągniętych zobowiązań z tytułu zaciągniętych pożyczek i kredytów). Zatem wskazany limit zobowiązań, w tym dotyczących kredytów konsolidacyjnych, określony tym przepisem jest obligatoryjnym elementem uchwały budżetowej.

Podsumowując powyższe, należy jednoznacznie stwierdzić, że kwotowy przychód z tytułu zaciągniętego kredytu konsolidacyjnego oraz limit zobowiązań z tytułu kredytów zaciągniętych na spłatę wcześniej zaciągniętych zobowiązań (tzw. rolowanie kredytu) musi zostać określony w treści uchwały budżetowej. W konsekwencji podjęcie przez organ stanowiący jednostki samorządu terytorialnego uchwały o zaciągnięciu kredytu konsolidacyjnego na spłatę wcześniej zaciągniętych zobowiązań w postaci kredytów, których wysokość nie została określona w uchwale budżetowej, stanowi istotne naruszenie prawa ${ }^{6}$.

Analizując zagadnienie dotyczące oceny skutków prawnych związanych z zaciąganiem kredytów konsolidacyjnych w świetle wymogów ustawy o finansach publicznych, należy również skierować uwagę na postanowienia art. 243 u.f.p. W obecnym stanie prawnym norma ta wyznacza limit zadłużenia liczony indywidualnie dla każdej jednostki samorządu terytorialnego ustalony według algorytmu przewidzianego tym przepisem. Jej celem jest zapobieżenie sytuacji

6 Por. wyroki Wojewódzkiego Sądu Administracyjnego: w Gdańsku z 11 lutego 2015 r., sygn. akt I SA/Gd 1389/14, oraz w Rzeszowie z 12 czerwca 2007 r., sygn. akt I SA/Rz 400/07, http://orzeczenia.nsa.gov.pl. 
niewypłacalności samorządu i utraty długookresowej płynności, a także przeciwdziałanie zjawisku finansowania działalności bieżącej (operacyjnej) środkami obcymi. W art. 243 ust. 1 ustawy przewidziano, że: [o] rgan stanowiacy jednostki samorzadu terytorialnego nie może uchwalić budżetu, którego realizacja spowoduje, że $w$ roku budżetowym oraz $w$ każdym roku następujacym po roku budżetowym relacja łącznej kwoty przypadajacych $w$ danym roku budżetowym:

1) spłat rat kredytów $i$ pożyczek, o których mowa $w$ (cytowanym powyżej) art. 89 ust. 1 pkt 2-4 oraz art. 90, wraz z należnymi $w$ danym roku odsetkami od kredytów i pożyczek, o których mowa wart. 89 ust. 1 i art. 90,

2) wykupów papierów wartościowych emitowanych na cele określone w art. 89 ust. 1 pkt 2-4 oraz art. 90 wraz z należnymi odsetkami i dyskontem od papierów wartościowych emitowanych na cele określone w art. 89 ust. 1 i art. 90,

3) potencjalnych spłat kwot wynikajacych z udzielonych poręczeń oraz gwarancji

do planowanych dochodów ogółem budżetu przekroczy średnią arytmetyczna z obliczonych dla ostatnich trzech lat relacji jej dochodów bieżacych powiększonych o dochody ze sprzedaży majątku oraz pomniejszonych o wydatki bieżace, do dochodów ogółem budżetu, obliczonq według wzoru (...).

Wszystkie wskazane wyżej i obowiązujące obecnie unormowania ustawy o finansach publicznych prowadzą do kategorycznego wniosku, że zaciągnięcie przez jednostkę samorządu terytorialnego kredytu konsolidacyjnego (w tym również takiego, który nie wydłużając terminu zakończenia spłat, zmieniłby ich harmonogram) musi znaleźć odzwierciedlenie w uchwale budżetowej, poprzez jego właściwe ujęcie. Zaciągnięcie kredytu długoterminowego na spłatę wcześniejszych zobowiązań stanowi nowy tytuł dłużny, gdyż kreuje nowy stosunek zobowiązaniowy między jednostką samorządu terytorialnego a kredytodawcą, dlatego musi znajdować oparcie w wielkościach zaplanowanych w uchwale budżetowej, w postaci ujęcia zarówno przychodów, jak i rozchodów z tytułu nowego kredytu. W rezultacie zaciągnięcie kredytu konsolidacyjnego jest przychodem w rozumieniu art. 5 ust. 1 pkt 4 u.f.p., a jego spłata stanowi rozchód, o którym mowa w art. 6 ust. 2 pkt 1 u.f.p. Powoduje to następstwo w takiej postaci, że fakt wzięcia omawianego kredytu musi wpływać w sposób bezpośredni na indywidualny limit zadłużenia (wskaźnik zadłużenia) wynikający z art. 243 ust. 1 u.f.p.

Powyższego stanowiska nie zmienia treść powołanej przez Prezydenta Miasta Przemyśla w piśmie z 17 stycznia 2018 r. uchwały nr 6 Krajowej Rady Regionalnych Izb Obrachunkowych z 10 czerwca 2011 r. w sprawie kredytów konsolidacyjnych, zgodnie z którą: Krajowa Rada Regionalnych Izb Obrachunkowych stoi na stanowisku, że zaciagnięcie kredytu konsolidacyjnego na spłatę zobowiązań zaciagniętych przez jednostkę samorządu jest możliwe przy spełnieniu warunków określonych w ustawie o finansach publicznych.

1. Konsolidacja długu gminnego (j.s.t.) jest możliwa przy zachowaniu progów dopuszczalnego zadtużenia. 
2. Konsolidacja - umowa o kredyt konsolidacyjny - może być oparta o różne konstrukcje prawne, takie jak np. odnowienie (506-507 kc [Kodeksu cywilnego dopisek H.D.]), wstapienie w prawa zaspokojonego wierzyciela ( $518 \$ 1$ pkt $3 \mathrm{kc}$ ), podstawienie w prawa wierzyciela, zwalniające przejęcie dtugu (519 kc), umowa o zwolnienie z długu (392 kc), spełnienie świadczenia za dłużnika (356 kc), a także inne umowy mieszane lub nienazwane.

3. Konsolidacja długu gminnego jest możliwa, jeżeli wymienione wyżej umowy nie znajduja odzwierciedlenia w obrotach na rachunku bankowym gminy - dłuznika (tzw. pozabilansowa operacja na długu), a także wtedy, gdy takie odzwierciedlenie nastapi, lecz nie doprowadzi to do naruszenia progów dopuszczalnego zadtużenia.

Wymieniona uchwała formułuje jedynie stanowisko Krajowej Rady Regionalnych Izb Obrachunkowych, niemające mocy powszechnie obowiązującej, i w swej preambule oraz treści uzależnia możliwość zaciągnięcie kredytu konsolidacyjnego od spełnienia warunków określonych w ustawie o finansach publicznych. W pkt 1 i 3 uchwała sygnalizuje wyraźne obowiązek zachowania progów dopuszczalnego zadłużenia przy konsolidacji długu jednostki samorządu terytorialnego ${ }^{7}$.

W konsekwencji również Krajowa Rada Regionalnych Izb Obrachunkowych dostrzega, że przy wskazaniu skutków zawierania kredytu konsolidacyjnego nie można pomijać bezwzględnie obowiązujących regulacji zawartych w ustawie o finansach publicznych, które wymagają tego, aby uwzględnić takie zobowiązanie w uchwale budżetowej (jako przychód i rozchód). Zaznaczenia wymaga też to, że przepisy ustawy o finansach publicznych nie czynią w tym względzie jakichkolwiek wyjątków dla spłat dokonywanych w ramach konsolidacji zadłużenia. Także w orzecznictwie sądów administracyjnych podkreśla się, że zagadnienie dotyczące uzyskiwania przez jednostki samorządu wszelkich kredytów: jest bowiem uwarunkowane regulacjami ustawy o finansach publicznych, która określając zasady planowania i dysponowania środkami publicznymi, normuje zasady zaciagania zobowiązań przez jednostki samorządu terytorialnego ${ }^{8}$.

Biorąc pod uwagę wszystkie przedstawione wyżej uwarunkowania, należy dojść do wniosku, że w obecnym stanie prawnym wszelkie czynności związane z zaciąganiem kredytu konsolidacyjnego muszą być uwzględnione (jako przychód i rozchód) w uchwale budżetowej, wpływając tym samym na wysokość indywidualnego wskaźnika zadłużenia. Brak stosowania wobec tego typu operacji uchwały budżetowej i nieuwzględnianie kredytu konsolidacyjnego w toku ustalania wskaźnika zadłużenia oznaczałoby, iż omawiane zobowiązanie de facto

7 Cyt. za: wyrok WSA w Gliwicach z 14 października 2015 r., sygn. akt I SA/Gl 949/15, http://orzeczenia.nsa.gov.pl.

8 Zob. wyrok NSA z 17 października 2017 r., sygn. akt II GSK 227/16, http://orzeczenia. nsa.gov.pl. 
nie byłoby objęte ustawą o finansach publicznych, która w swych założeniach reguluje wszelkie operacje finansowe wnikające $\mathrm{z}$ funkcjonowania jednostki samorządu. W konsekwencji taki stan rzeczy stanowiłby swoistą formę obejścia postanowień obowiązującej ustawy.

Powyższe realia prawne wskazują wyraźnie, że nie zasługuje na uwzględnienie proponowana przez Prezydenta Miasta Przemyśla możliwość skierowania „wytycznych” dla regionalnych izb obrachunkowych celem spowodowania, aby rozchód związany ze spłatą kredytów konsolidacyjnych nie wpływał negatywnie na ocenę stanu zadłużenia, bowiem skutkowałoby to swoistym wyłączeniem stosowania postanowień ustawy o finansach publicznych. Co więcej, ustawa z 7 października 1992 r. o regionalnych izbach rozrachunkowych (t.j. Dz.U. 2016, poz. 561, ze zm.) w art. 2 ust. 1 wyraźnie wskazuje, że nadzór nad działalnością regionalnych izb obrachunkowych sprawuje minister właściwy do spraw administracji publicznej wyłącznie na podstawie kryterium zgodności z prawem (legalności). Również same izby kontrolują gospodarkę finansową, w tym realizację zobowiązań podatkowych oraz zamówienia publiczne jednostek samorządu terytorialnego przede wszystkim na podstawie kryterium zgodności z prawem (art. 5 ust. 1 ustawy o regionalnych izbach rozrachunkowych). Skoro zatem w świetle funkcjonujących obecnie regulacji ustawy o finansach publicznych odpowiadające obowiązującemu prawu (legalne) jest stanowisko - znajdujące swe oparcie także w orzecznictwie wojewódzkich sądów administracyjnych oraz Naczelnego Sądu Administracyjnego - zgodnie z którym kredyt konsolidacyjny wpływa na stan przychodów i rozchodów danej jednostki samorządu, to uznać należy, że nie istnieje pole do działań zmierzających do kierowania wytycznych dla regionalnych izb obrachunkowych celem zmiany istniejącego stanu rzeczy. Wytyczne takie (swoją drogą nieprzewidziane w samej ustawie o izbach rozrachunkowych) nie mogłyby bowiem prowadzić do dokonania interpretacji obowiązujących norm wbrew ich jednoznacznej i precyzyjnej treści.

Wszystkie przedstawione wyżej czynniki dowodzą jednoznacznie, że na gruncie obowiązujących regulacji ustawy o finansach publicznych nie istnieje możliwość, aby zaciągnięty kredyt konsolidacyjny nie mógł być nieuwzględniony jako przychód i rozchód w uchwale budżetowej danej jednostki samorządu oraz nie wpływał na indywidualny wskaźnik zadłużenia.

Aktualna staje się zatem w tym miejscu druga kwestia poruszona przez Prezydenta Miasta Przemyśla, dotycząca celowości dokonania zmiany obowiązujących przepisów ustawy o finansach publicznych, zmierzających do tego, aby uzyskanie przez jednostki samorządu terytorialnego kredytu konsolidacyjnego było w praktyce możliwe.

Za nowelizacją obecnych unormowań może przemawiać argument, że zaciągnięcie kredytu konsolidacyjnego nie powinno być przychodem (a jego spłata rozchodem w rozumieniu ustawy o finansach publicznych), ponieważ kwota uzyskanego świadczenia podlega bezpośredniemu przekazaniu przez bank, któ- 
ry go udziela, dotychczasowym kredytodawcom. Istotą tej operacji jest zatem jedynie konwersja długu, a jej pozabilansowy charakter sprawia, że nie powinna ona znaleźć odzwierciedlenia w uchwale budżetowej i wieloletniej prognozie finansowej. Innymi słowy, zaciągnięcie kredytu konsolidacyjnego jest operacją pozabilansową na istniejącym już długu, polegającą na zamianie wcześniej zaciągniętych kredytów na jeden, dogodniej rozłożony w czasie lub niżej oprocentowany. W rzeczywistości jednostka samorządu przychody nim objęte uzyskała już wcześniej, a konsolidacja doprowadza tylko do scalenia długów w jeden, korzystniejszy. Pod względem ekonomicznym nie zwiększają się też rozchody budżetu z tytułu spłaty takiego kredytu, bo nie zwiększy się ogólne zadłużenie jednostki. Wskazuje się również, że konsolidacja zadłużenia ma głównie na celu refinansowanie długu i zastąpienie wysoko oprocentowanych kredytów i pożyczek nowym, zaciągniętym na atrakcyjniejszych warunkach, co może się przełożyć korzystnie na strukturę zadłużenia jednostki samorządu terytorialnego, co z kolei skutkuje zazwyczaj zmniejszeniem rocznych obciążeń budżetu lub zamianą na instrument o niższym oprocentowaniu9. Z drugiej jednak strony pamiętać należy, iż działania restrukturyzacyjne mogą skutkować też negatywnymi konsekwencjami w postaci wzrostu kosztów obsługi zadłużenia jednostek samorządu terytorialnego ${ }^{10}$. Konsolidacja wiąże się często $\mathrm{z}$ wydłużeniem okresu spłat, a to pociąga za sobą spłaty dodatkowych odsetek, które nalicza także bank konsolidujący. W ostateczności może to prowadzić do zwiększenia ostatecznych kosztów spłaty całości zadłużenia.

Mając na względzie m.in. wskazane wyżej realia o charakterze ekonomicznym, w Ministerstwie Rozwoju i Finansów opracowano projekt nowelizacji ustawy o finansach publicznych ${ }^{11}$, znajdujący się obecnie na etapie uzgodnień. Projekt ten wychodzi naprzeciw oczekiwaniom wynikającym $\mathrm{z}$ analizowanego pisma Prezydenta Miasta Przemyśla, bowiem przewiduje możliwość dokonywania przez jednostki samorządu terytorialnego restrukturyzacji długu poprzez m.in. spłatę istniejącego zadłużenia nowym, korzystniejszym długiem konsolidacyjnym. Inicjatywa ustawodawcza Ministra Rozwoju i Finansów ma w swych zamierzeniach pozwolić na racjonalizację gospodarki finansowej i jednocześnie na zmniejszenie długu publicznego i kosztów jego obsługi. Proponowany nowy przepis art. 243 ust. 3 a pkt 2 u.f.p. przewiduje niestosowanie ograniczenia w spłacie zobowiązań w przypadku restrukturyzacji zadłużenia jednostki samorządu terytorialnego w formie wcześniejszej spłaty istniejącego zadłużenia poprzez za-

\footnotetext{
9 Zob. wyrok WSA w Rzeszowie z 8 maja 2014 r., sygn. akt I SA/Rz 221/14.

10 Zob. D. Jurewicz, Wybrane zagadnienia związane z restrukturyzacja zadtużenia jednostek samorządu terytorialnego na przykładzie samorządów województwa kujawsko-pomorskiego, „Prawo Budżetowe Państwa i Samorządu” 2013, nr 1, s. 77 i n.

11 Projekt z 11 kwietnia 2017 r., numer UD 229, https://legislacja.rcl.gov.pl/docs//2/122 97351/12426490/12426491/dokument284119.pdf.
} 
ciągnięcie nowego długu o niższych kosztach obsługi, przy czym ustalenie kosztów obsługi następować będzie w całym okresie spłaty ${ }^{12}$.

Biorąc pod uwage przedstawione okoliczności związane z wdrożonym przez Ministra Rozwoju i Finansów procesem legislacyjnym, przyjąć należy, że istnieje duże prawdopodobieństwo, iż inicjatywa ta doprowadzi do uchwalenia zmian w ustawie o finansach publicznych, które przyczynią się do zaistnienia stanu prawnego obejmującego uwzględnianie kredytów konsolidacyjnych, zgodnego z oczekiwaniami Prezydenta Miasta Przemyśla. Nowelizacja ta będzie miała w konsekwencji również pozytywny wpływ na możliwość skorzystania przez miasto Przemyśl i inne podobne ośrodki miejskie z programu „Pakiet dla średnich miast".

\section{Bibliografia}

Jurewicz D., Wybrane zagadnienia zwiąane z restrukturyzacja zadłużenia jednostek samorządu terytorialnego na przykładzie samorządów województwa kujawsko-pomorskiego; „Prawo Budżetowe Państwa i Samorządu” 2013, nr 1, https://doi.org/10.12775/ pbps.2013.005.

Lipiec-Warzecha L., Komentarz do ustawy o finansach publicznych, LEX.

12 Uzasadnienie projektu, https://legislacja.rcl.gov.pl/docs//2/12297351/12426490/1242 6491/dokument284123.pdf. 